\title{
CHEMMOTOLOGY
}

\section{CURRENT PARADIGM AND GROWTH PROSPECTS OF CHEMMOTOLOGY}

\author{
A. F. Aksenov, E. P. Seregin, L. S. Yanovskii, and S. V. Boichenko
}

This article describes the development of the modern paradigm of chemmotology as a set of concepts, definitions, and terms and shows the importance of modern chemmotological terminology.

Key words: paradigm, chemmotology, fuel, lubricating materials, quality.

An analysis of the etymology of the term chemmotology shows that it was first used by K. K. Panok in 1964 [1-13]. Panok defined chemmotology as "a new science that studies the chemico-motor, physico-motor, and service properties of fuels, lubricants, and technical fluids and develops ways of using them efficiently in technology." The definition of chemmotology was later refined to "the science of the properties, quality, and efficient use of fuel, lubricants, and technical fluids in technology." Yet another definition appeared later - the theory and practice of the efficient use of fuels and lubricants. In a monograph published by adherents

of K. K. Panok in 1985, chemmotology was characterized as "the applied science of the service properties, quality, and efficient use of fuels, oils, lubricants, and technical fluids in technology." With allowance for the 1964 publications, a more complete definition of chemmotology was offered in 2005: "a technical applied science concerning the properties, quality, and efficient use of fuel, lubricants, and technical fluids in technology”[6-13].

We are proposing to refine chemmotology's definition as "the science of the technologies, properties, quality, and methodology of efficient use of fuels, oil, lubricants, and technical fluids in engineering applications." This definition includes not only oils but alternative fuel-lubricant materials (FLMs) and technical fluids (TFs).

As a science, chemmotology has long had a social mandate to develop methods and equipment for making efficient use of petroleum products. However, this mission has yet to be fulfilled because of the law that dictates

National Aviation University (Ukraine). 25th State Research Institute of Chemmotology of the Ministry of Defense of the Russian Federation. Central Scientific-Research Institute of Aircraft Engine Design (Russia). Translated from Khimiya i Tekhnologiya Topliv i Masel, No. 4, pp. 13 - 19, July - August, 2013. 
the growth of science "in reserve." In accordance with this law, the necessary reserve of knowledge must be accumulated before any scientific-technical problem can be solved. Chemmotology has not yet accumulated enough information on the methodology attending the efficient use of petroleum products. As always, such information requires continual actualization. Lacking that, it is impossible to successfully resolve the fundamental and applied problems associated with the efficient use of fuels, oils, lubricants, and technical fluids.

Scientists and engineers need to recognize that chemmotology has developed relatively independently as a science. First of all, the basic sciences obviously play the leading role. The basic sciences necessarily progress faster than the applied sciences, since this is the only way in which an adequate knowledge base can be established. Secondly, it has become clear that each chemmotological problem needs to be formulated in such a way as to properly relate its scientific aspects with the associated industrial and economic issues. As the history of science shows, the true importance of a problem that is being or has already been solved often does not become apparent until after a period of time has elapsed. Here, the more fundamental the knowledge that is already "in reserve," the more valuable it turns out to be for industry.

Thus, we see the natural internal logic of science's development. Its findings sometimes come too late to be of significant practical value, while in other cases scientific discoveries are "ahead of their time." The practical problems that were encountered as science and engineering were progressing in the middle of the Twentieth Century led to the creation of a new applied science - chemmotology. Chemmotology first demonstrated its value in helping to solve important problems in equipment design, fabrication, and use and the development and use of fuels, oils, lubricants, and TFs. Further improvements in the performance and reliability of engines, machines, and mechanisms would not have been possible without the improvements that were made in the service properties

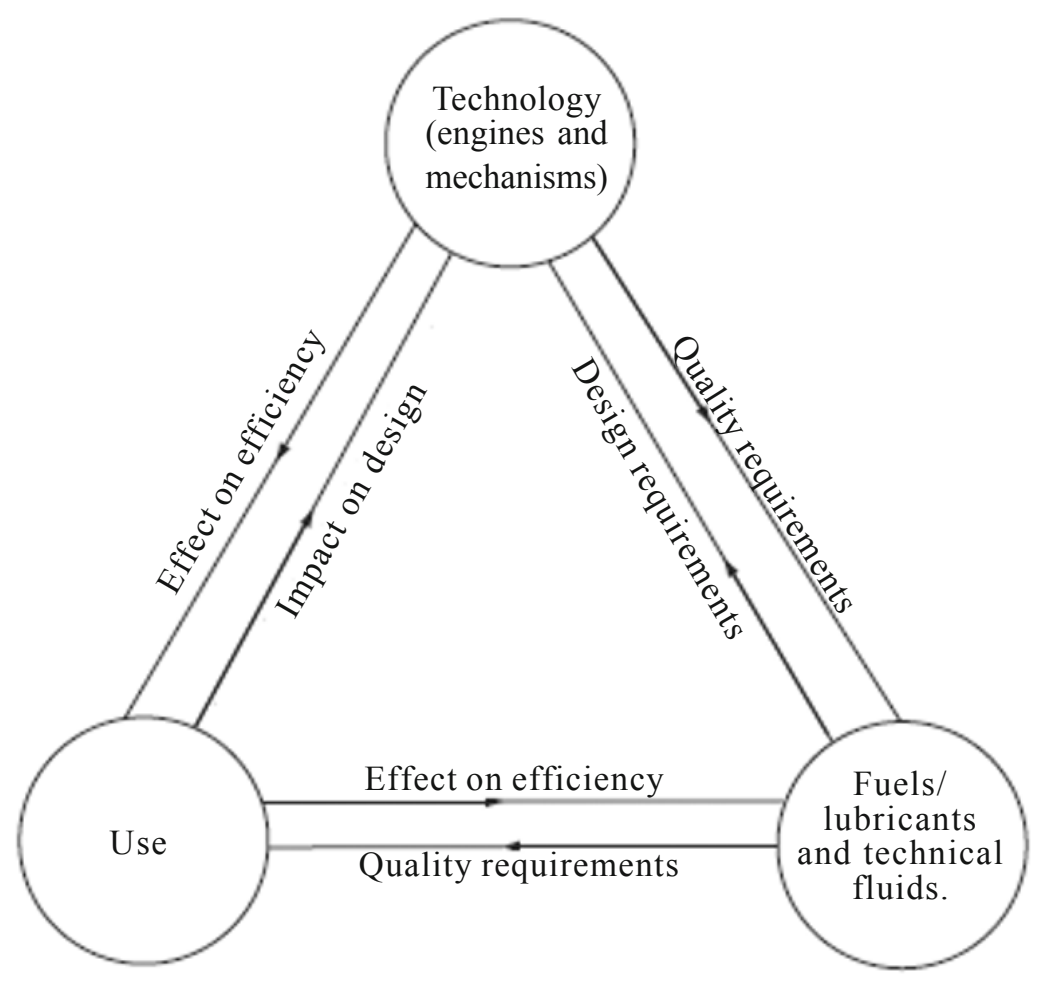

Fig. 1. Refined universal three-component chemmotological system. 
of FLMs and TFs. That is why we are seeing not only a continual increase in the amounts of fuels and lubricants that are being used but also a tightening of requirements on their quality and an improvement in their characteristics.

Chemmotology was initially characterized by a systems approach [14-23]. As with systems engineering, chemmotology is a branch of science and engineering that includes the design, fabrication, testing, and use of complex systems; to a certain extent, it is a practical embodiment of systems theory. A generalized function characterizing the value of FLMs as socially useful products (in contrast to a generalized function characterizing the utility of transportation equipment) cannot be described by a set of design drawings and charts. Herein lies the main difference between FLMs and the products made by machine plants, and it has become an additional objective factor in the growth of chemmotology as a science.

The current role of chemmotology is illustrated by the importance of the problems that it is helping to solve: ensuring that the economy's energy sector is safe and secure; making efficient use of fuels, lubricants, and TFs in the realization of existing technologies and the development of new ones. The systems approach in chemmotology is not so much a method of solving problems as it is a way of formulating them. This is qualitatively more important than its function as thematic learning tool.

The main issues in chemmotology at present can be ranked in the following order:

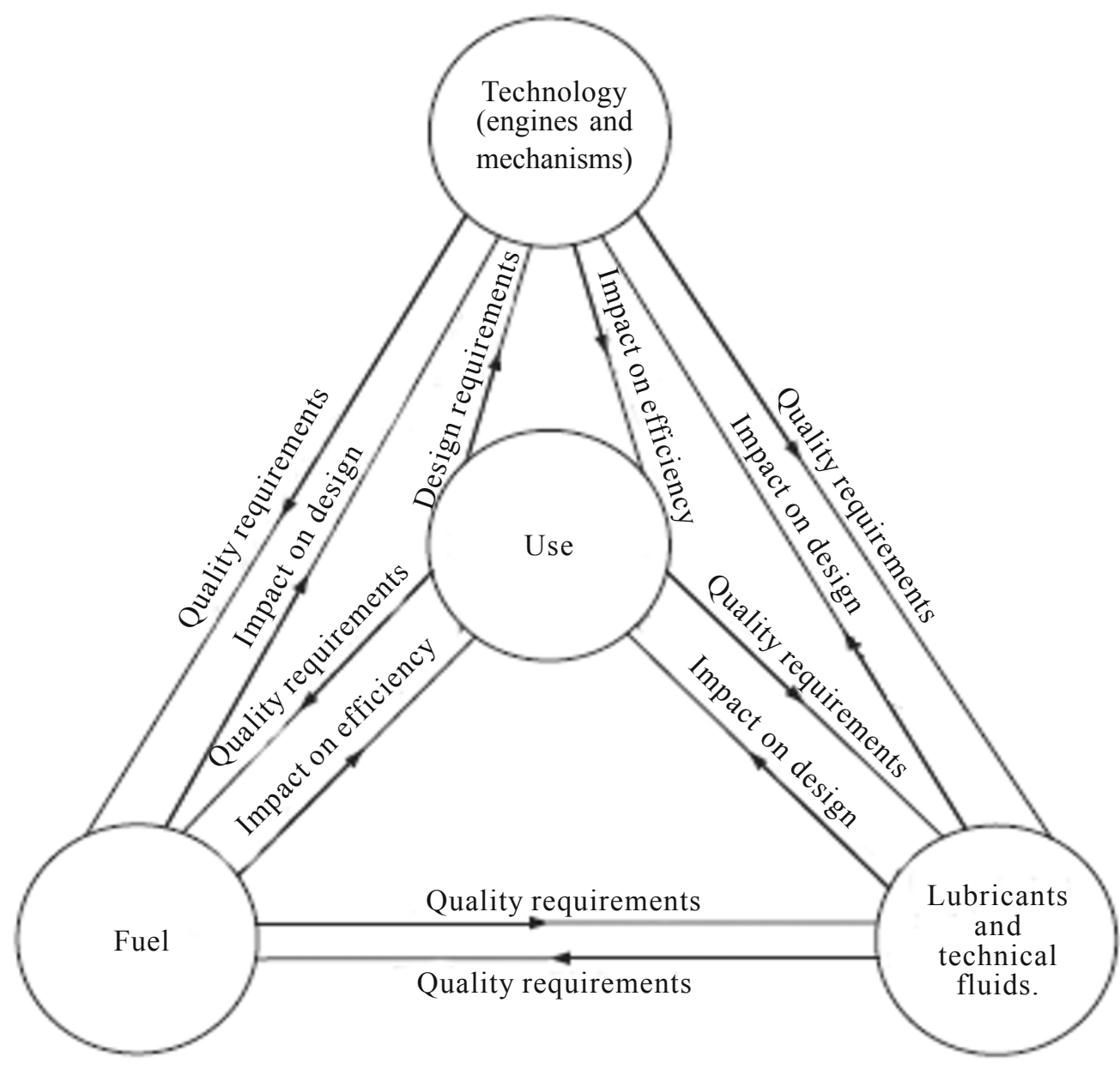

Fig. 2. Refined four-component chemmotological system. 
- optimizing existing requirements on the quality, composition, and service properties of fuels, lubricants, and TFs with allowance for existing reserves of primary energy sources, scientific and technical improvements to technology, aspects of its design and the conditions under which it is used, and environmental and economic requirements;

- developing recommendations on making fuels, lubricants, and TFs more standardized and interchangeable and determining the conditions for their efficient, cost-effective use;

- modernization of engines and machinery.

It possible to discern two trends in the modernization of the technology: the invention and practical introduction of new, highly economical types of engines; improvement of all existing types of engines.

Technological improvements are currently being made in the following areas:

- improvement of the aerodynamic characteristics of transportation equipment;

- reduction in energy use by this equipment;

- provision of transportation equipment with control systems and systems to indicate the optimum parameters for the fuel feed into the combustion chamber, preparation of the fuel mixture, and combustion of the fuel, as well as equipment performance and environmental characteristics;

- implementation of organizational measures designed to reduce unit FLM consumption;

‘ improvement of fuel and oil supply networks and the quality control of FLM production, storage, transport, and use;

-modernization of the systems used to evaluate compliance (certification, testing, and permitting of manufacturing and use) and the methods used for certification tests of fuels, lubricants, and TFs;

- review of Russian and international standards on test methods for fuels, lubricants, and TFs to bring them into better alignment with one another;

- invention of efficient new fuels, lubricants, and TFs in order to improve the environmental and performance characteristics of machines and mechanisms;

- recycling and processing of off-grade and used FLMs;

- development of organizational-technical measures to maintain the quality and reduce the losses of FLMs during storage, pumping, and transport;

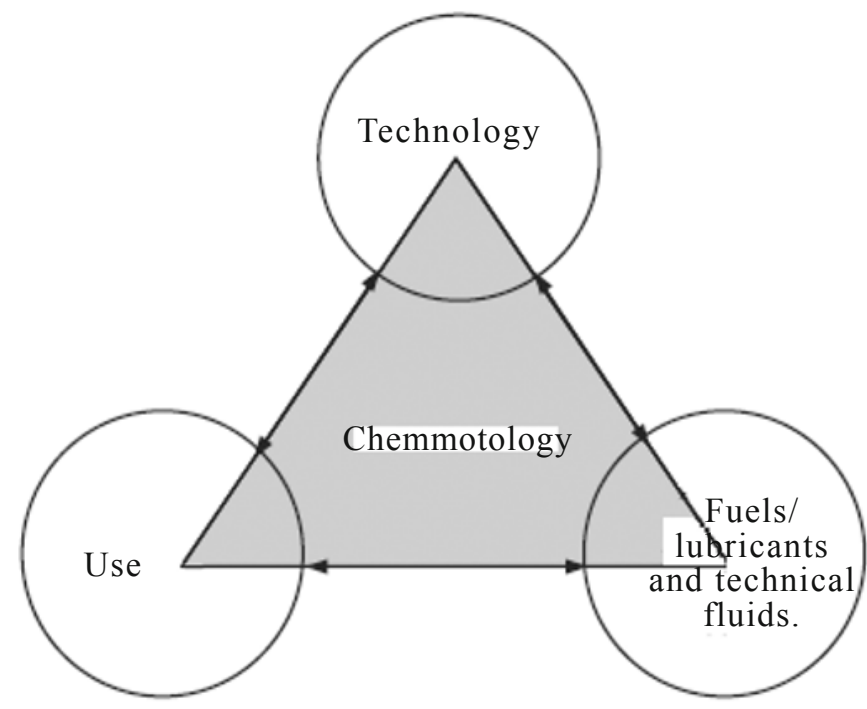

Fig. 3. Place and role of chemmotology in the integrated system "technology - FLM - use." 


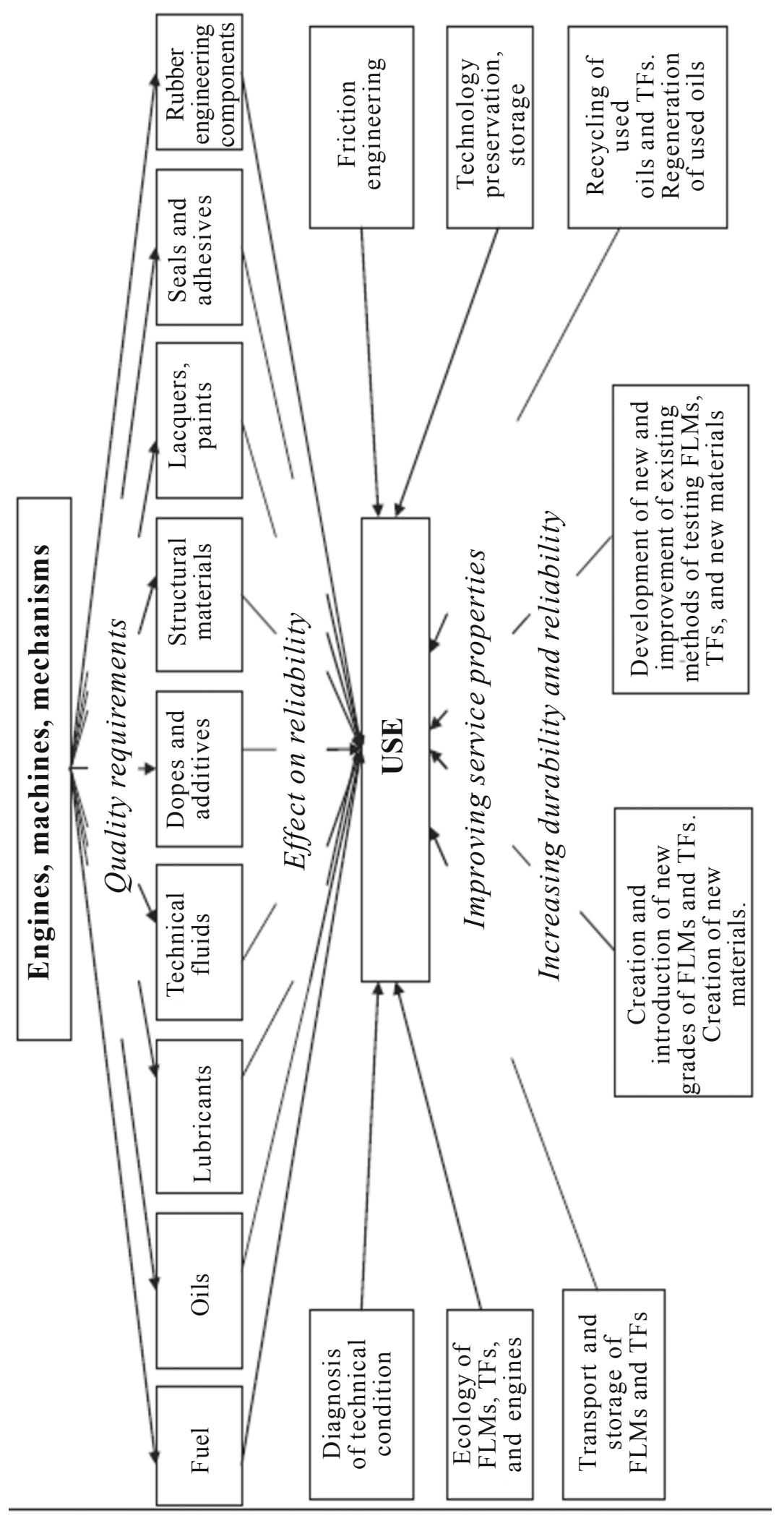

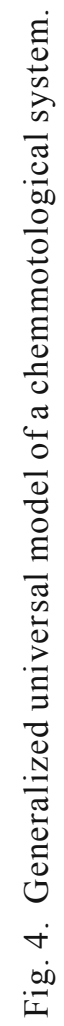




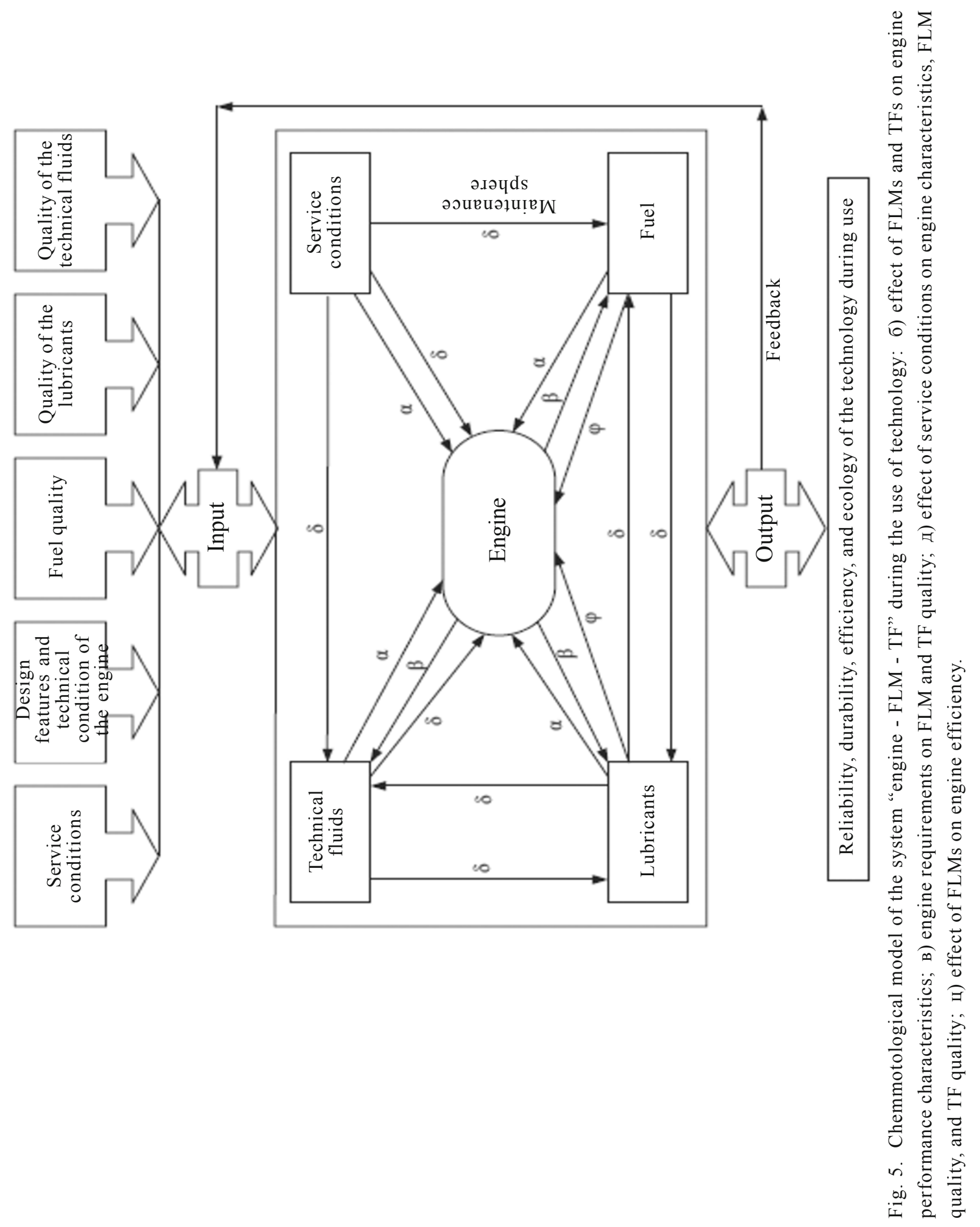


- development of methods for evaluating the service properties of FLMs and monitoring their quality;

- improvement of existing technologies for FLM use and the creation of new such technologies.

The complex of interrelated elements in the system "FLM and TF - technology - use" - elements that are connected to one another by different physico-chemical processes - constitutes a chemmotological system. The processes by which the elements of a chemmotological system interact with one another (Fig. 1) are the main object of study and essence of chemmotology.

Figure 2 presents a more accurate picture of the relationship between the elements of a chemmotological system and depicts the essence of chemmotology as a science.

The above four-element system can be adapted to suit any type of technology, its exact modification depending on the specific problems that are being solved. Figure 3 [24-26] shows the place of chemmotology in the solution of the scientific-technical problems that are encountered in technology development and use. Figure 4 presents a generalized universal model of a chemmotological system.

The focus of research in chemmotology is the service properties of fuels, lubricants, and TFs.

The main scientific-technical mission of chemmotology is the efficient use of fuels, oils, lubricants, and TFs in technology.

The economic essence of chemmotology is maximizing the conservation of raw materials, FLMs, and TFs by optimizing the volumes of production and quality of the finished products and making efficient use of them.

The theoretical and engineering foundations of chemmotology are:

- constructing a theory and discovering laws that relate the quality of FLMs and TFs to the reliability, durability, ecology, economy, and efficiency of technologies;

- substantiating the optimum requirements on the quality of FLMs and TFs;

- selecting (developing) new grades of FLMs and TFs;

- standardizing types and grades of FLMs and TFs;

- maintaining the quality of FLMS and TFs;

- studying the physico-chemical, environmental, and service characteristics of FLMs and TFs during their storage, transport, and distribution;

- reducing unit costs and normalized losses of FLMs and TFs;

- reducing the volume of work required to monitor the quality of FLMs and TFs;

- developing methods of reconditioning FLMs and TFs;

- solving problems related to the interchangeability of grades of FLMs and TFs made by different manufacturers;

- developing methods, equipment, and systems for determining the service properties and quality indices of FLMs and TFs;

- protecting the environment from the effects of chemmotological systems (Fig. 5).

In light of the specific features of chemmotology as an applied science, one should not expect that its general principles will find quantitative expression in the form of fundamental laws. At the same time, the knowledge that has been accumulated in this field to date is adequate to state the most general law of chemmotology in qualitative form: the service properties of fuels, lubricants, and special liquids are determined by the composition of their components and the structure and energy state of their molecules; the extent to which their intended service properties are fully realized depends on the design features of the engines (mechanisms) in which they are used and the external conditions that impact an FLM [24-26]. 


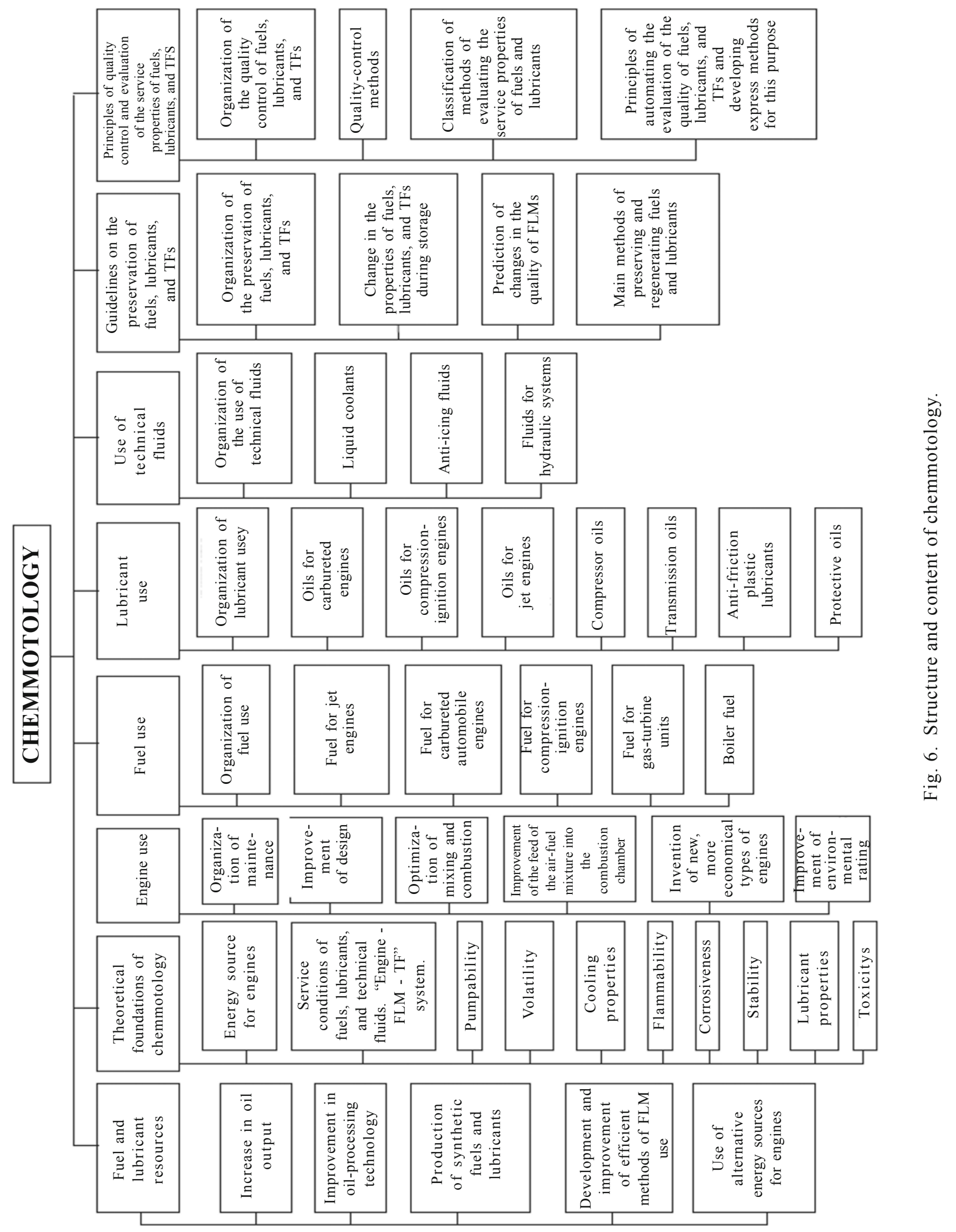




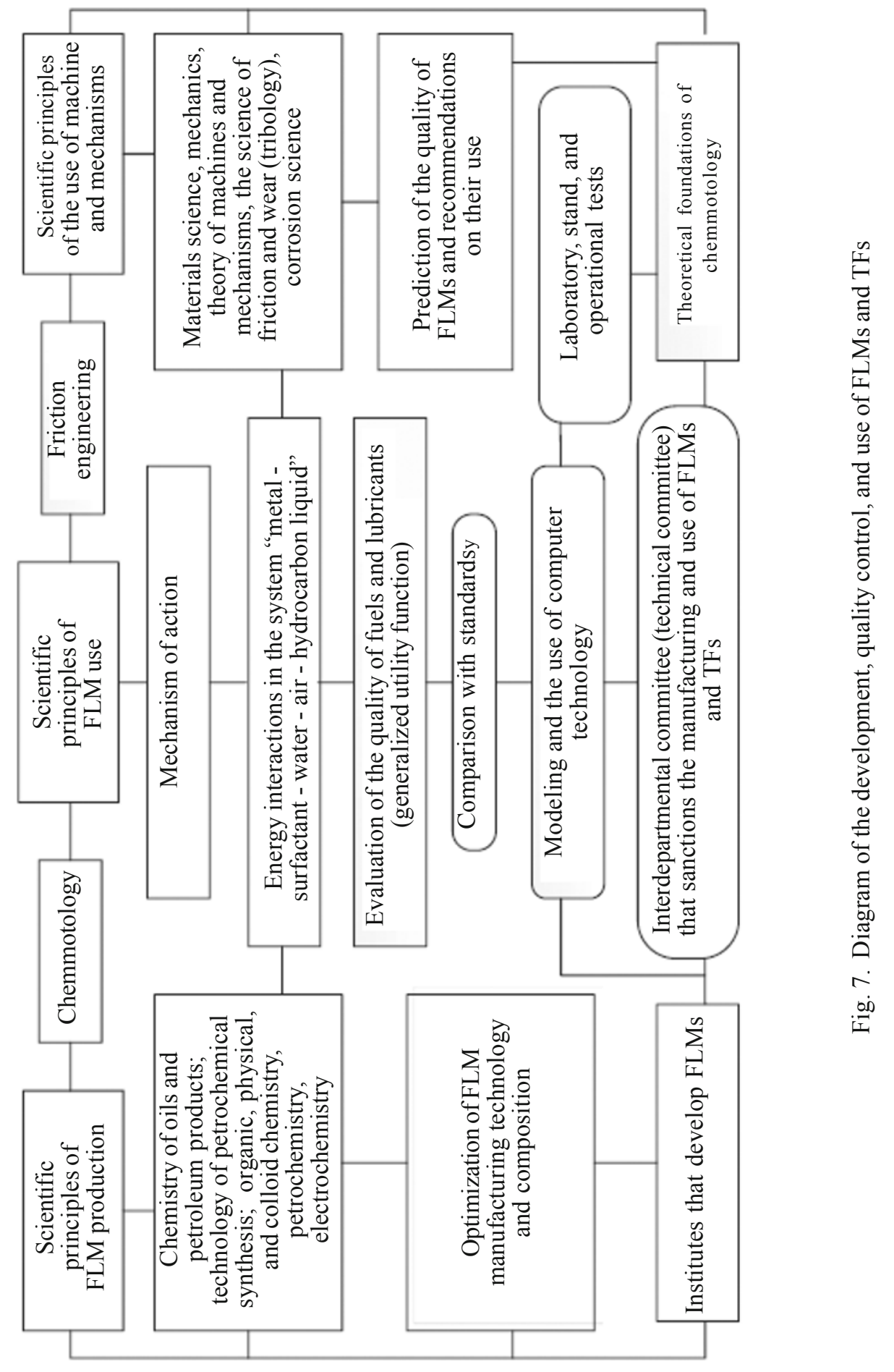


Chemmotology provides the necessary "foundation" for optimizing the service conditions of FLMs and TFS and updating requirements on their quality and effective use in technology. Figure 6 shows the structure and content of chemmotology as a science.

One issue that is of particular importance in chemmotology is monitoring the quality of an FLM from the time it leaves the manufacturer until the time it reaches the customer.(see Fig. 6). The use of FLMs with quality indices (a quality rating) that are unnecessarily high increases production costs, while the use of FLMs with quality indices that are substandard increases the cost of machine construction and practical use of the FLM in technology.

If we look at the example of the octane number used for gasolines in piston engines in which the fuel-air mixture is ignited by sparkplugs, it can be seen that the increase in this number has allowed designers to develop engines which exhibit superior dynamic characteristics, have improved size/weight indices, and consume less fuel. The choice between the poor anti-wear properties and high thermal stability of jet fuels and between the poor anti-wear properties and improved environmental characteristics (low sulfur content) of diesel fuels has led to the development of high-pressure aviation fuel pumps and diesel unit injectors that are not sensitive to the anti-wear properties of these respective fuels. Designers of aviation equipment are resolving the problem of having to avoid the use of anti-icing liquids by managing the temperature regime of the fuel filters so as to prevent their obstruction by ice crystals during flight.

It is possible to identify specific problems that are characteristic of the use of technology. One such problem is the cleanliness of FLMs, i.e. the presence of mechanical impurities, water, microorganisms, and other contaminants that should not be in fuels and lubricants when they are shipped from the manufacturer but may enter an FLM during its transport, storage, pumping, and other operations. Also characteristic of the use of technology is the deterioration that takes place in the quality of FLMs as a result of their evaporation, the accumulation of oxidation products, the precipitation or washing out of certain additives, the mixing of different grades of FLMs, etc.

The main theoretical content of FLM chemmotology consists of relations that describe the service properties or composition of fuels, lubricants, and TFs. Here, the main role is played by the main component of the given FLM. For example, the hydrocarbon mixture determines the density of aviation-grade kerosines, the initial octane number of gasolines, the low-temperature properties of diesel fuels, the viscosity of motor oils, etc. However, a single pure substance is used as the FLM only in special cases, such as in liquid rocket fuels $\left(\mathrm{O}_{2}, \mathrm{H}_{2}, \mathrm{H}_{2} \mathrm{O}_{2}\right.$, etc. $)$. Even in those instances, in the absence of hydrocarbon mixtures, the decisive role is sometimes played by impurities, special additives, or particular components of the base. Impurities and additives have a significant effect on the properties of hydrocarbon mixtures. For example, sulfur compounds in hydrocarbon fuels determine their environmental and corrosion properties, while oxygen-bearing compounds largely determine the thermal stability of jet fuels, the octane number of gasolines, and the anti-wear properties of jet fuels and diesel fuels.

Figure 7 presents a diagram showing the relationships between different stages in the development, production, quality control, multistage testing, and use of FLMs and TFs.

Thus, an innovative methodology for chemmotology has been formulated in this investigation and the main concepts and current problems of chemmotology have been described. The prospects for further development of chemmotology's theoretical foundations were discussed. The survey substantiates and validates the new thinking that has come about in the area of the use of fuels, oils, lubricants, technical fluids, and additives to ensure the reliable operation of transportation equipment. 


\section{REFERENCES}

1. Theoretical Foundations of Chemmotology [in Russian] (Ed: A. A. Bratkov). Khimiya, Moscow (1985).

2. Chemmotology of Rocket and Jet Fuels [in Russian], (Ed: A. A. Bratkov). Khimiya, Moscow (1987).

3. A. A. Gureev, I. G. Fuks, and V. L. Lakhshi, Chemmotology [in Russian], Khimiya, Moscow (1987).

4. Fuels and Lubricants: Encyclopedic Dictionary-Handbook [in Russian], (Ed; V. M. Shkol'nikov). Tekhinform, Moscow (2007).

5. L. S. Yanovskii, N. F. Dubovkin, F. M. Galimov, et al. Engineering Foundations of Aviation Chemmotology [in Russian], Izd. Kazan. Univ. (2005).

6. A. Aksenov, S. Boichenko, and V. Terekhin, Neft' i Gaz, No. 1, 74-79 (2009).

7. A. Aksenov and S. Boichenko, Ibid., No. 7, 90-92 (2008).

8. S. Boichenko, V. Novikova, L. Chernyak, et al., in: Problems of Ukrainian Terminology: 3b. Scientific Terms [in Ukrainian], NU “L’vivs'ka Politekhnika,” Lvov (2008), pp. 102-104.

9. V. V. Sereda and S. N. Volgin, Khim. Tekh. Topliv i Masel, No. 5, 3-6 (2004).

10. A. A. Bratkov, Ibid., No. 5, 7-10 (2004).

11. N. N. Grishin, V. L. Lashkhi, and A. I. Egin, ibid., No. 5, 16-17 (2004).

12. V. L. Lashkhi and N. N. Grishin, Ibid., No. 5, 41-45 (2004).

13. E. D. Radchenko and Yu. N. Shekhter, Ibid., No. 4, $2-5$ (1987).

14. L. S. Yanovskii, V. P. Dmitrenko, N. F. Dubovkin, et al., Foundations of Aviation Chemmotology [in Russian], MATI, Moscow (2005).

15. N. N. Grishin, A. I. Echin, V. L. Lashkhi, et al., Scientific-Technical Principles of the Chemmotology of Lubricants [in Russian], Tekhnika, Moscow (2006).

16. G. F. Bolshakov, Physico-Chemical Principles of the Use of Fuels and Oils [in Russian], Nauka, Novosibirsk (1987)

17. I. G. Fuks, V. G. Sprikin, and T. N. Shabalina, Foundations of Chemmotology. Chemmotology in the Oil and Gas Industry [in Russian], Neft' i Gaz, Moscow (2004).

18. A. M. Danilov, Introduction to Chemmotology [in Russian], Tekhnika, Moscow (2003).

19. V. A. Piskunov, V. N. Zrelov, V. T. Vasilenko, et al., Chemmotology in the Aviation Industry [in Russian], Transport, Moscow (1983).

20. S. V. Boichenko and V. G. Spirkin, Introduction to the Chemmotology of Fuels and Oils: Two-Part Primer [in Ukrainian], Avstroprint, Odessa (2009).

21. S. V. Boichenko, Neft' i Gaz, No. 1, 92-94 (2003).

22. S. V. Boichenko, Ekotekhnologiya i Resursosberezhenie, No. 2, 31-35 (2003).

23. A. Zaporozhets, S. Boychenko, V. Tokarev, et al., in: Proc. Third World Congress "Aviation in the XXI ${ }^{\text {st }}$ Century," September 22-24, 2008, Kiev (2008), pp. 4.1-4.4.

24. E. P. Seregin, Visnik NAU, No. 1, 89-94 (2009).

25. S. N. Volgin, V. L. Lashkhi, and N. N. Grishin, Ibid., No. 1, 104-107 (2009).

26. V. V. Sereda, V. L. Lashkhi, and N. N. Grishin, Mir Neftproduktov, No. 6, 4-6 (2008). 